\title{
Physicochemical and Sensory Characteristics of a Chagalapoli Fruit (Ardisia compressa) Beverage Fermented Using Saccharomyces cerevisiae
}

\author{
Ana Flores-García, Rubén Márquez-Meléndez, Erika Salas, Guillermo Ayala-Soto, \\ Iván Salmerón, and León Hernández-Ochoa \\ Universidad Autónoma de Chihuahua, Facultad de Ciencias Químicas, Departamento de Posgrado, Circuito Universitario, \\ Campus Universitario \#2, Chihuahua C.P. 31125, Mexico \\ Correspondence should be addressed to León Hernández-Ochoa; lhernandez@uach.mx
}

Received 21 February 2019; Accepted 28 April 2019; Published 13 October 2019

Academic Editor: Salam A. Ibrahim

Copyright (c) 2019 Ana Flores-García et al. This is an open access article distributed under the Creative Commons Attribution License, which permits unrestricted use, distribution, and reproduction in any medium, provided the original work is properly cited.

\begin{abstract}
Chagalapoli fruit (Ardisia compressa) is similar to Vaccinium myrtillus (berries) with high-polyphenol content. The objective of this study was to evaluate the physicochemical properties of Chagalapoli fruit and to determine the conditions for the preparation of a fermented beverage using Saccharomyces cerevisiae yeast, evaluating the impact on sensory properties. The fermentation process lasted 4 days at $27^{\circ} \mathrm{C}$, with absence of light and a fixed $\mathrm{pH}$ of 3.8. The phenolic contents obtained in samples were 1.27 epicatechin $\mathrm{mg} / \mathrm{mL}$ in filtered juice, 1.59 epichatechin $\mathrm{mg} / \mathrm{mL}$ in filtered fermented beverage, 1.91 epichatechin $\mathrm{mg} / \mathrm{mL}$ in partially filtered juice and 3.19 epichatechin $\mathrm{mg} / \mathrm{mL}$ in partially filtered fermented beverage. An affective test was carried out to determine the sensory acceptability of the final product, evaluating the flavor, color and aroma parameters. The fermented beverage with the greatest preference on color and flavor attributes was the partially filtered fermented beverage.
\end{abstract}

\section{Introduction}

Chagalapoli (Ardisia compressa subsp. Myrsinaceae) belongs to the Myrsinaceae family, an extensive family of trees with approximately 500 species [1]. The chagalapoli fruit has a round shape of approximately $12 \mathrm{~mm}$ in diameter, with a purple red color that turns black once it reaches maturity; its shell is smooth and delicate, its seed represents up to $50 \%$ of its total weight, and the ripe fruit has a bittersweet, mildly astringent taste [2]. In Mexico it is distributed in the states of Chihuahua, Chiapas, San Luis Potosí, Tlaxcala, Hidalgo, Aguascalientes, Puebla, Tamaulipas and Veracruz [3]. Chagalapoli fruit has a similar composition to common berries with a high phenolic content; that is the reason for the high interest in this fruit from a health point of view [4]. The fruit is used to make food products such as juices, jams, and liqueurs, considered to possess antioxidant and antimicrobial properties. In the state of Veracruz the fruit is used against digestive diseases [5]. Chandra and Mejia [6] quantified the total polyphenols of the Ardisia compressa leaf extract, obtaining values of $0.58 \mathrm{mg}$ of gallic acid equivalent per $\mathrm{mL}$ $\mathrm{mgGAE} / \mathrm{mL}$ DL. They identified the presence of gallic acid, catechin, epicatechin gallate, ardisin and kaempferol. HerediaVasquez [3] determined the total polyphenol content of chagalapoli fruit and obtained $1.74 \mathrm{mgGAE} / \mathrm{mL}$ in Ardisia compressa kunth; Joaquín-Cruz et al. [4] obtained $1.051 \pm 0.43 \mathrm{mgEAG} / \mathrm{g}$ and identified the polyphenols of flavonols, flavan-3-ols (catechin and proantocyanidin dimers) and hydroxycinnamoyl derivatives. Jácome-Hernandez [2] obtained $1,638.12 \pm 74.98 \mathrm{mgGAE} / \mathrm{kg}$ in dry weight (DW). Fermented beverages, such as grape wines, have been associated with health benefits due to the presence of large amounts of phenolic compounds, which are claimed to possess antioxidant properties and have an important role in the prevention of deleterious processes such as ageing, diabetes, cancer, neurological disorders, atherosclerosis and cardiovascular diseases [7]. Moreover, several studies have shown that these beverages induce relaxation in isolated vessels, which makes them important allies for cardiovascular protection [8]. This means that it is necessary to carry out 
research studies focused on the physicochemical characterization of the fruit and the process of making a fermented beverage that will promote the potential of the chagalapoli fruit. For this reason, the aim of this work was to evaluate the physicochemical properties of the chagalapoli (Ardisia compressa) fruit and determine the conditions for the preparation of a fermented beverage using Saccharomyces cerevisiae, evaluating the impact on the physicochemical and sensory properties of the final product.

\section{Material and Methods}

2.1. Materials. Acetonitrile and formic acid were highperformance liquid chromatography grade. Glucose, Epicatechin, Kaempferol, Quercetin, Catechin, Chlorogenic and Folin-Ciocalteu reagents were provided by Sigma-Aldrich. Milli-Q water was produced using an Elix Millipore water purification system.

2.2. Raw Material. Chagalapoli (Ardisia compressa) fruit was collected in Aguascalientes, Mexico. $20 \mathrm{~kg}$ were manually selected and washed with chlorine $(0.05 \mathrm{~mL} / \mathrm{L})$. Samples were stored at $4^{\circ} \mathrm{C}$ for further analysis.

2.3. Characterization of Raw Material. Proximal analysis of chagalapoli (Ardisia compressa) was determined according to the AOAC methods; protein (976.05) determined by Micro kjeldahl (Nx6.25), moisture (934.06), ash (942.05), fat (920.39), crude fiber (962.09) and carbohydrates.

2.4. Must Preparation. Chagalapoli fruit was extracted using a destoner machine (Bertuzzi, Brugherio, Milan, Italy) with a 0.2 sieve separating the seed. The experiment was divided into two batches: Filtered juice (all crushed fruit was filtered), and partially filtered juice (75\% filtered crushed fruit and $25 \%$ unfiltered fruit). The filtration consisted in separating residues from the juice by centrifugation. Must was prepared according to the methods of Dias et al. [9], with minor modifications. Tartaric acid was added to adjust $\mathrm{pH}$ to 3.8 in order to inhibit bacterial growth, and sulfur dioxide was added in the form of potassium metabilsulfite at concentrations of $100 \mathrm{mg} / \mathrm{L}$.

2.5. Yeast Strains. Commercial Saccharomyces cerevisiae yeast was used and the inoculum was done following the recommendations of the manufacturer (Red Star brand, provided by Maltas e Insumos Cerveceros S.A. de C.V.). $0.173 \mathrm{~g}$ of dried yeast was added to $173 \mathrm{~mL}$ of warm water with $1.73 \mathrm{~g}$ of sucrose at $35-38^{\circ} \mathrm{C}$ for $20 \mathrm{~min}$, it was left to cool for $10 \mathrm{~min}$. Initial cell density of yeast was $1.9 \times 10^{6} \pm 0.2$ cells $/ \mathrm{mL}$.

2.6. Fermentation Conditions. Once the must preparation is done according to 2.4 and yeast inoculum is done according to 2.5 were intro out in a $1 \mathrm{~L}$ bioreactor (BioBundle, Applikon Biotechnology, Netherlands) at $27^{\circ} \mathrm{C}$. Fermentation process was evaluated every $24 \mathrm{~h}$ and considered complete when the specific gravity was stable. At the end of the fermentation, the beverage was transferred to a glass bottle and stored at $10^{\circ} \mathrm{C}$. After $24 \mathrm{~h}$, the beverage was transferred to a new bottle and after 10 days the beverage was filtered and stored at $5^{\circ} \mathrm{C}$ in $350 \mathrm{~mL}$ glass bottles filled to the top to avoid oxygen entrance [11].

2.7. Analysis of Juice and Fermented Beverage. Titratable acidity (TAC), specific gravity, $\mathrm{pH}$, cell counts (Neubauer chamber, Celeromics France) total soluble solids (TSS) were determined according to García and Xirau [12]. Sulfur dioxide, volatile acidity (VA) and alcoholic strength by volume were determined after fermentation and storage using methods of the International Organisation of Vine and Wine [13]. Colorimetric properties were measured in terms of CIELAB parameters using a colorimeter model CR400 (Konica Minolta sensing NJ USA) and expressed in terms of rectangular $\left(L^{*}, a^{*}, b^{*}\right)$ color coordinates. $L^{*}$ indicates lightness ranging from black (0) to white (100). $a^{*}$ value ranges from red to green and $b^{*}$ ranges from yellow to blue.

2.8. Determination of Reducing Sugar. The reducing sugar was obtained using the method of Miller [14]. Briefly, $0.5 \mathrm{~mL}$ of sample was added with $0.5 \mathrm{~mL}$ of 3,5-dinitrosalicylic acid (DNS) reagent, kept in a boiling water bath for 5 minutes then the reaction was stopped by placing the test tubes in a cold water bath, $5 \mathrm{~mL}$ of distilled water was added and it was left to rest for 15 minutes. Absorbance was determined at $540 \mathrm{~nm}$ in an Absorbance microplate reader model EL $\times 808$ (Biotek VT USA). All the experiments were performed in triplicate. The reducing sugar content was calculated based on a standard glucose curve.

2.9. Determination of Total Sugar. The total sugar content was determined using the method of Dubois [15], Chow and Landhausser [16]. $2 \mathrm{~mL}$ of sample was diluted in $2 \mathrm{~mL}$ of $5 \%$ phenol solution; it was boiled in a water bath for $5 \mathrm{~min}$ and then cooled with ice. Then $5 \mathrm{~mL}$ of $\mathrm{H}_{2} \mathrm{SO}_{4}$ was added and it was stirred, then it was left to rest during $30 \mathrm{~min}$. Absorbance was determined at $490 \mathrm{~nm}$ in an Absorbance microplate reader. All experiments were performed in triplicate.

2.10. Total Phenolic Content. The total phenolic content was determined using the method of Folin-Ciocalteu [17]. $30 \mu \mathrm{L}$ of sample was diluted in $3 \mathrm{~mL}$ of water and $200 \mu \mathrm{L}$ of FolinCiocalteu reagent and $600 \mu \mathrm{L}$ of a sodium carbonate solution was added. Afterwards this sample was warmed up at $40^{\circ} \mathrm{C}$ for $20 \mathrm{~min}$, then it was cooled to room temperature and after $15 \mathrm{~min}$ the absorbance was measured at $760 \mathrm{~nm}$. Total phenolic content was calculated as gallic acid equivalent based on a standard gallic acid curve. All the experiments were performed in triplicate.

2.11. HPLC-DAD Analysis. Samples were filtered through a $0.45 \mu \mathrm{m}$ membrane filter (Millipore Corporation). Samples were analyzed on an Agilent 1100 HPLC (Agilent, Technologies CA USA) equipped with a diode detector, with wavelengths at $280 \mathrm{~nm}, 320 \mathrm{~nm}$ and $360 \mathrm{~nm}$. A C18 column (Phenomenex) was used for the stationary phase. The mobile phase consisted of two solvents: (A) water/formic acid (99:1; v/v), and (B) acetonitrile (100\%). The gradient employed was: isocratic $0 \% \mathrm{~B}$ for $8 \mathrm{~min}$, $10 \% \mathrm{~B}$ for $2 \mathrm{~min}, 20 \% \mathrm{~B}$ for $13 \mathrm{~min}, 30 \% \mathrm{~B}$ for $7 \mathrm{~min}, 40 \% \mathrm{~B}$ for $15 \mathrm{~min}, 80 \% \mathrm{~B}$ for $5 \mathrm{~min}, 100 \% \mathrm{~B}$ for $5 \mathrm{~min}$. Flow rate was set at $1 \mathrm{~mL} / \mathrm{min}$ and a temperature of $25^{\circ} \mathrm{C}$. Phenolic identities were assigned based on their retention characteristics and UVvisible spectra. For the identification and quantification of total 
TABle 1: Proximal composition and physicochemical characteristics of chagalapoli (Ardisia compressa) fruit.

\begin{tabular}{lc}
\hline Components $^{\mathrm{a}}$ & Value \\
\hline Water (\%) & $80.52 \pm 0.8$ \\
Ether extract (\%) & $0.55 \pm 0.05$ \\
Ash (\%) & $0.66 \pm 0.01$ \\
Protein (\%) & $8.58 \pm 0.4$ \\
Crude fiber (\%) & $3.58 \pm 0.005$ \\
Carbohydrates (\%) & 11.9 \\
Water activity & $0.97 \pm 0.001$ \\
TSS & $(\%)$ \\
pH & $17.7 \pm 0.05$ \\
\hline
\end{tabular}

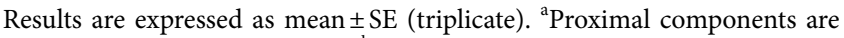
expressed in fresh weight (FW). ${ }^{\mathrm{b}}$ Total soluble solids ( ${ }^{\circ} \mathrm{Brix}$ ).

phenolics compounds external standard calibration curves of the reported compounds were used (Epicatechin, Kaempferol, Quercetin, Catechin, Chlorogenic).

2.12. Sensory Analysis. The final beverages were evaluated by a panel of 32 adult men and women. $20 \mathrm{~mL}$ samples at $10^{\circ} \mathrm{C}$ were given in transparent glasses marked with threedigit random numbers. Fermented beverages were evaluated by acceptability for appearance (color), aroma and flavor according to a 5-point hedonic scale were 0 correspond to least appreciated (dislike extremely) and 5 correspond to most appreciated (like extremely).

2.13. Statistical Analysis. Data for all of the measurements were obtained in triplicate and expressed as mean \pm standard deviation. Statistical analyses during fermentation $(\mathrm{pH}$, relative density, total soluble solids (TSS) and total titratable acidity (TAC)) were performed with a one-way analysis of variance and means comparison (Tukey). Fermented beverages (filtered and partially filtered beverages) were compared with the filtered and partially filtered juices by means of a $t$-test to determine the significant difference between samples. A significance level $p<0.05$ was adopted. Different letters were used to label significantly different values. This statistical treatment was carried out using Minitab 17 Statistical Software.

\section{Results and Discussion}

3.1. Physicochemical Characteristics of Ardisia compressa. Results obtained in the proximal composition are shown in Table 1. The water content of the fruit was $80.5 \%$, similar to values reported by Joaquin-Cruz et al. [4] who reported $86.8 \%$ in Ardisia compressa from Veracruz. The Chagalapoli fruit used in this research had a $\mathrm{pH}$ level of $4.2 \pm 0.1$. This result was higher than the values reported by Jacome-Hernandez [2] ( $\mathrm{pH}$ 2.91) and Joaquin-Cruz et al. [4] ( $\mathrm{pH}$ 2.73). Likewise, total soluble solids were different from those reported by Jacome-Hernandez [2] (10.5\%), while our results were $17.7 \pm 0.05 \%$. This could be attributed to the fact that each fruit comes from different locations, weather conditions, harvest season, storage, etc. that affect the characteristics of each fruit. Low $\mathrm{pH}$ could contribute to a decrease of general sensory quality of the beverage to an unacceptable level [18].

3.2. Analysis during Fermentation. Table 2 shows the results obtained of $\mathrm{pH}$, specific gravity, total soluble solids (TSS) and total titratable acidity (TAC). It was observed that $\mathrm{pH}$ values of the beverages did not have a significant difference during the fermentation process, in fermented filtered chagalapoli the change was from $3.84 \pm 0.04$ to $3.62 \pm 0.09$ and in fermented partially filtered it was from $3.87 \pm 0.2$ to $3.54 \pm 0.1$. The TAC did not exhibit significant difference in either of the batches $(8.9 \mathrm{~g} / \mathrm{L}$ to $8.6 \mathrm{~g} / \mathrm{L}$ for the filtered sample and $8.9 \mathrm{~g} / \mathrm{L}$ to $9.2 \mathrm{~g} / \mathrm{L}$ tartaric acid for the partially filtered sample); in fermented fruit the limit values are $5.5 \mathrm{~g} / \mathrm{L}$ to $9 \mathrm{~g} / \mathrm{L}$ (Norma Oficial Mexicana PROY-NOM-199-SCFI-2015) which indicates that TAC obtained in the filtered sample is within the permitted limits. Specific gravity showed significant difference between samples, which showed a tendency to decrease with time; batches had the same value at the end of fermentation. During alcoholic fermentation of both batches of Ardisia compressa, initial value of yeast was $1.9 \times 10^{6} \pm 0.2$ cells $/ \mathrm{mL}$. Number of microorganisms increases due to environmental conditions and sugar content decreases rapidly. Maximum value of yeasts was obtained on the second day with an amount with density of $4.1 \times 10^{7} \pm 0.1$ cells $/ \mathrm{mL}$; this is relevant because it suggests that at this point the yeast was in optimal conditions that favor the production of alcohol. A decrease of cell density was observed after the third day and fermentation concluded without a significant difference on the fourth day with a value of $4.4 \times 10^{6} \pm 0.2$ cells $/ \mathrm{mL}$.

3.3. Color Parameters. Table 3 shows CIELAB color parameters obtained. $L^{*}$ value was $27.5-30.34$ in the filtered sample and 30.75-31.09 in the partially filtered sample. It was observed that values increased during fermentation, which indicates the samples are darker. $a^{*}$ obtained in filtered samples was 8.87-8.42 and in partially filtered samples was 7.15-6.92. It was observed that values decreased during fermentation which indicates a red tone. $b^{*}$ values was $14.50-$ 17.50 in filtered samples and $16.59-16.28$ in partially filtered samples, which indicates they $b^{*}$ values increased in the filtered samples and decreased in partially filtered samples, obtaining a yellow color. Angle of hue and chromaticity defined the sample within the red color, presenting significant differences in all samples. Heredia-Vasquez [3] reported different values in $L^{*}$, $a^{*}$ and $b^{*}$, obtained low luminosity and more tendency towards red color. Differences can be justified by the type of fruit used as well as by climatic condition, region, harvest time, etc.

3.4. Analysis of Fermented Beverage. Fermented filtered and partially filtered beverage of chagalapoli (Ardisia compressa) fruit obtained a similar result in alcoholic degree method, $6 \%$ and 6.4\% respectively. Official Mexican Standard NOM199-SCFI-2017 specifies the limit values for fermented fruit beverages from $6 \%$ to $12 \%$; the values obtained from chagalapoli (Ardisia compressa) fermented beverage are within the established range. Chowdhury and Ray [19] reported a $6 \%$ of alcohol content in a fermented jamun berry (Syzygium cumini L.) beverage. 
TABLE 2: Physicochemical properties of chagalapoli (Ardisia compressa) fruit filtered and partially filtered beverage during fermentation.

\begin{tabular}{|c|c|c|c|c|c|c|c|c|c|c|}
\hline \multirow[b]{2}{*}{ Days } & \multicolumn{5}{|c|}{ Filtered fermented beverage } & \multicolumn{5}{|c|}{ Partially filtered fermented beverage } \\
\hline & 0 & 1 & 2 & 3 & 4 & 0 & 1 & 2 & 3 & 4 \\
\hline $\mathrm{pH}$ & $\begin{array}{l}3.84 \pm \\
0.04^{\mathrm{a}}\end{array}$ & $\begin{array}{l}3.75 \pm \\
0.06^{\mathrm{ab}}\end{array}$ & $\begin{array}{l}3.65 \pm \\
0.07^{\mathrm{ab}}\end{array}$ & $\begin{array}{l}3.61 \pm \\
0.09^{\mathrm{b}}\end{array}$ & $\begin{array}{l}3.62 \pm \\
0.09^{b}\end{array}$ & $3.87 \pm 0.2^{\mathrm{a}}$ & $3.74 \pm 0.07^{\mathrm{a}}$ & $3.5 \pm 0.1^{\mathrm{a}}$ & $3.51 \pm 0.1^{\mathrm{a}}$ & $3.54 \pm 0.1^{\mathrm{a}}$ \\
\hline SP. $\mathrm{Gr}^{1}$ & $\begin{array}{c}1.072 \pm \\
0.005^{\mathrm{a}}\end{array}$ & $\begin{array}{l}1.048 \pm \\
0.007^{\mathrm{b}}\end{array}$ & $\begin{array}{l}1.028 \pm \\
0.001^{c}\end{array}$ & $\begin{array}{l}1.009 \pm \\
0.001^{\mathrm{d}}\end{array}$ & $1.004 \pm 0^{\mathrm{d}}$ & $1.074 \pm 0^{\mathrm{a}}$ & $\begin{array}{l}1.044 \pm \\
0.002^{\mathrm{b}}\end{array}$ & $\begin{array}{l}1.030 \pm \\
0.003^{c}\end{array}$ & $\begin{array}{l}1.006 \pm \\
0.001^{\mathrm{d}}\end{array}$ & $\begin{array}{l}1.004 \pm \\
0.001^{\mathrm{d}}\end{array}$ \\
\hline $\mathrm{TSS}^{2}(\%)$ & $\begin{array}{c}17.5 \pm \\
0.1^{\mathrm{a}}\end{array}$ & $\begin{array}{c}11.16 \pm \\
0.2^{\mathrm{b}}\end{array}$ & $\begin{array}{c}7.09 \pm \\
0.3^{\mathrm{c}}\end{array}$ & $\begin{array}{c}2.34 \pm \\
0.2^{\mathrm{d}}\end{array}$ & $1.04 \pm 0^{\mathrm{d}}$ & $17.9 \pm 0^{\mathrm{a}}$ & $11.03 \pm 0.4^{\mathrm{b}}$ & $7.74 \pm 0.8^{c}$ & $1.7 \pm 0.2^{\mathrm{d}}$ & $1.2 \pm 0.2^{\mathrm{d}}$ \\
\hline $\begin{array}{l}\mathrm{TAC}^{3} \\
\text { (g/L tartaric } \\
\text { acid) }\end{array}$ & $8.9 \pm 0.1^{\mathrm{a}}$ & $8.6 \pm 0.2^{\mathrm{a}}$ & $8.6 \pm 0.08^{\mathrm{a}}$ & $8.6 \pm 0.1^{\mathrm{a}}$ & $8.6 \pm 0.08^{\mathrm{a}}$ & $8.9 \pm 0.1^{\mathrm{a}}$ & $9.1 \pm 0.2^{\mathrm{a}}$ & $9.3 \pm 0.05^{\mathrm{a}}$ & $9.2 \pm 0.1^{\mathrm{a}}$ & $9.2 \pm 0.2^{\mathrm{a}}$ \\
\hline
\end{tabular}

Results are expressed as mean \pm SE (triplicate). Values with same letter are not statistically different $(p<0.05) .{ }^{1}$ Specific gravity. ${ }^{2}$ Total soluble solids. ${ }^{3}$ Titratable acidity.

TABLE 3: Chagalapoli (Ardisia compressa) juice and fermented beverage color analysis.

\begin{tabular}{|c|c|c|c|c|c|}
\hline & $L^{*}$ & $a^{*}$ & $b^{*}$ & Chroma & Angle of hue $\left(h^{\circ}\right)$ \\
\hline Filtered juice & $27.50 \pm 0.005^{\mathrm{d}}$ & $8.87 \pm 0.02^{\mathrm{a}}$ & $5.63 \pm 0.02^{c}$ & $14.50 \pm 0.01^{\mathrm{d}}$ & $0.56 \pm 0.002^{\mathrm{d}}$ \\
\hline Filtered fermented beverage & $30.34 \pm 0.01^{\mathrm{c}}$ & $8.42 \pm 0.02^{\mathrm{b}}$ & $9.07 \pm 0.02^{\mathrm{b}}$ & $17.50 \pm 0.02^{\mathrm{a}}$ & $0.79 \pm 0.002^{c}$ \\
\hline Partially filtered juice & $30.75 \pm 0.04^{\mathrm{b}}$ & $7.15 \pm 0.03^{\mathrm{c}}$ & $9.44 \pm 0.02^{\mathrm{a}}$ & $16.59 \pm 0.03^{\mathrm{b}}$ & $0.87 \pm 0.002^{\mathrm{b}}$ \\
\hline Partially filtered fermented beverage & $31.09 \pm 0.09^{\mathrm{a}}$ & $6.92 \pm 0.06^{\mathrm{d}}$ & $9.36 \pm 0.09^{\mathrm{a}}$ & $16.28 \pm 0.03^{\mathrm{c}}$ & $0.87 \pm 0.006^{\mathrm{a}}$ \\
\hline
\end{tabular}

Results are expressed as mean \pm SE $(n=5)$. Values with same letter are not statistically different $(p<0.05)$.

TABLE 4: Reducing sugar, total sugar and total polyphenol contents in filtered and partially filtered Chagalapoli (Ardisia compressa) fruit juice and filtered and partially filtered fermented beverages.

\begin{tabular}{|c|c|c|c|c|c|c|c|c|}
\hline & \multirow{2}{*}{\multicolumn{2}{|c|}{$\begin{array}{l}\text { Reducing sugar } \\
\text { mg (glucose)/mL }\end{array}$}} & \multirow{2}{*}{\multicolumn{2}{|c|}{$\begin{array}{c}\text { Total sugar } \\
\text { mg (glucose)/mL }\end{array}$}} & \multicolumn{4}{|c|}{ Total polyphenols } \\
\hline & & & & & \multicolumn{2}{|c|}{$\begin{array}{c}\text { Folin-Ciocalteu } \\
\mathrm{mg}(\mathrm{GAE}) / \mathrm{mL}\end{array}$} & \multicolumn{2}{|c|}{$\begin{array}{l}\text { HPLC-DAD } \\
\mathrm{mg}(\mathrm{EPI}) / \mathrm{mL}\end{array}$} \\
\hline & Juice & Fermented & Juice & Fermented & Juice & Fermented & Juice & Fermented \\
\hline $\begin{array}{l}\text { Filtered } \\
\text { Chagalapoli }\end{array}$ & $132.08 \pm 1^{\mathrm{a}}$ & $3.42 \pm 0.3^{\mathrm{b}}$ & $137.82 \pm 0.9^{\mathrm{a}}$ & $3.74 \pm 0.1^{\mathrm{b}}$ & $1.8 \pm 0.03^{\mathrm{a}}$ & $1.11 \pm 0.02^{\mathrm{b}}$ & $1.07 \pm 0.04$ & $1.47 \pm 0.09$ \\
\hline $\begin{array}{l}\text { Partially filtered } \\
\text { Chagalapoli }\end{array}$ & $96.63 \pm 2^{\mathrm{a}}$ & $3.58 \pm 0.3^{\mathrm{b}}$ & $83.04 \pm 0.6^{\mathrm{a}}$ & $3.27 \pm 0.03^{\mathrm{b}}$ & $1.75 \pm 0.1^{\mathrm{a}}$ & $1.59 \pm 0.19^{\mathrm{b}}$ & $1.43 \pm 0.1$ & $2.86 \pm 0.01$ \\
\hline
\end{tabular}

Results are expressed as mean \pm SE (triplicate). Values with same letter are not statistically different $(p<0.05)$.

In relation to volatile acidity $0.32 \mathrm{~g} / \mathrm{L}$ was the value obtained for filtered fermented beverage and $0.36 \mathrm{~g} / \mathrm{L}$ for partially filtered beverage; Mena et al. [10] determined the volatile acidity of fermented beverages of 3 pomegranate varieties, for which they obtained values of $0.33,0.36$, and $0.26 \mathrm{~g} / \mathrm{L}$. These results obtained suggest that the sugar consumption produce different acids (citric, malic, acetic and tartaric acids).

The Official Mexican Standard NOM-199-SCFI-2017 allows a maximum $50 \mathrm{mg} / \mathrm{L}$ of free sulfur dioxide and $350 \mathrm{mg} / \mathrm{L}$ for total sulfur dioxide. To determine the sulfur dioxide in fermented beverages the free sulfur dioxide was calculated first; $17.06 \pm 0.73 \mathrm{mg} / \mathrm{L}$ was determined for free sulfur dioxide and $18.77 \pm 4.8 \mathrm{mg} / \mathrm{L}$ for total sulfur dioxide. For the total sulfur dioxide there was no significant difference between the samples, $57.6 \pm 3.3$ and $58.88 \pm 3.8$ were obtained, under the standard the samples are within the permitted limits. Oliveira et al. [11] reported similar results in cagaita wines (Eugenia dysenterica $D C$ ), they obtained from $22 \mathrm{mg} / \mathrm{mL}$ to $12 \mathrm{mg} / \mathrm{L}$ of total sulfur dioxide. Kelebek et al. [21] reported $8.2 \pm 0.08 \mathrm{mg} / \mathrm{L}$ of free sulfur dioxide and $73.3 \pm 0.12 \mathrm{mg} / \mathrm{mL}$ of total sulfur dioxide in orange wine.

3.5. Reducing Sugar. Results are shown in Table 4. The values for filtered juice and partially filtered juice were $132.08 \pm 1$ and $96.63 \pm 2 \mathrm{mg} / \mathrm{mL}$, respectively. For filtered and partially filtered fermented beverage, the values decreased to $3.42 \pm 0.3 \mathrm{mg} /$ $\mathrm{mL}$ and $3.58 \pm 0.3 \mathrm{mg} / \mathrm{mL}$, respectively. Similar results were reported by Oliveira et al. [11] where values of $1.2 \mathrm{mg} / \mathrm{mL}$ and $2.4 \mathrm{mg} / \mathrm{mL}$ of reducing sugars were obtained in Cagaita fruit wine.

3.6. Total Sugar Contents. Total sugar contents results are shown in Table 4. Filtered juice had more total sugars than partially filtered juice with $137.83 \pm 0.9 \mathrm{mg} / \mathrm{mL}$ and $83.04 \pm 0.6 \mathrm{mg} / \mathrm{mL}$, respectively. These results may be 


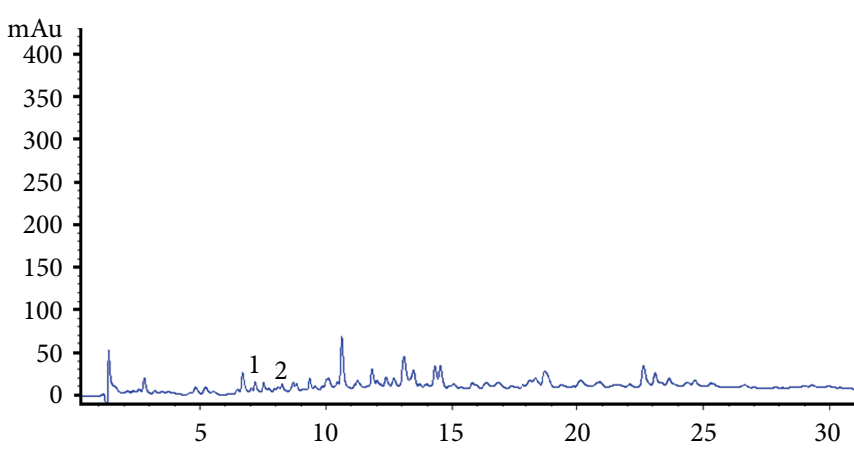

(a)

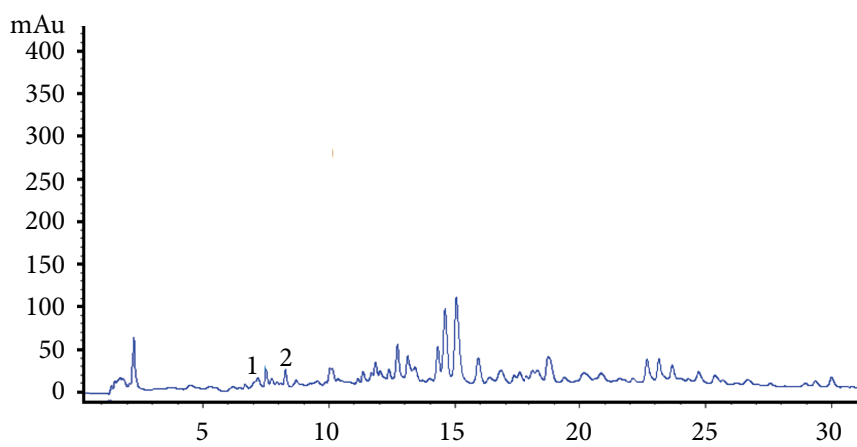

(c)

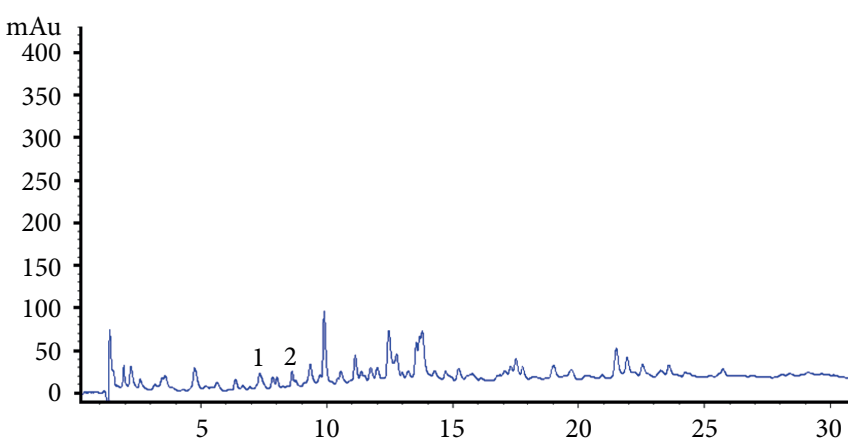

(b)

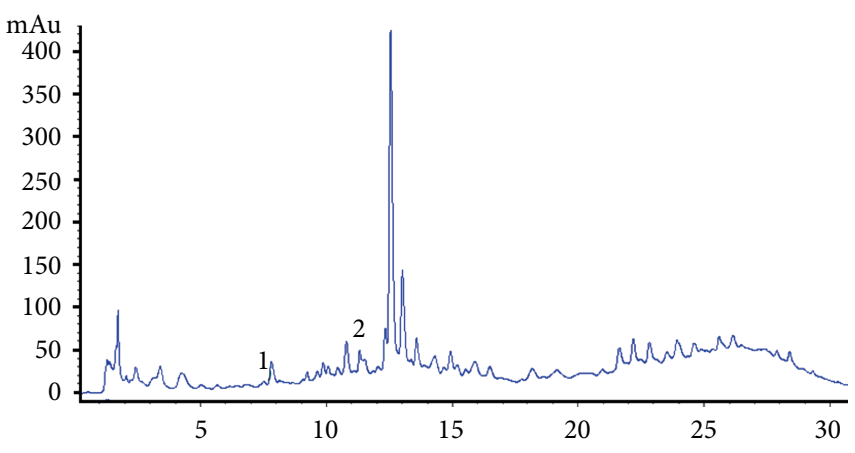

(d)

Figure 1: Chagalapoli (Ardisia compressa) HPLC Chromatograms at $280 \mathrm{~nm}$ : (a) filtered juice; (b) partially filtered juice; (c) filtered fermented beverage; (d) partially filtered fermented beverage.

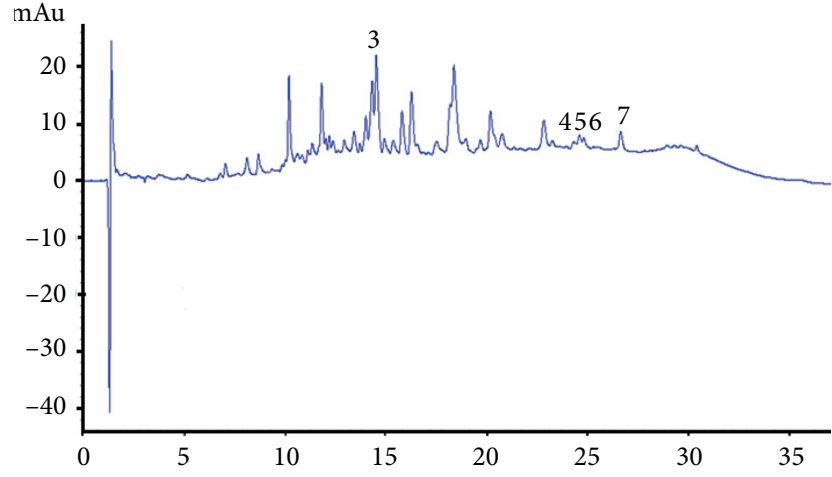

(a)

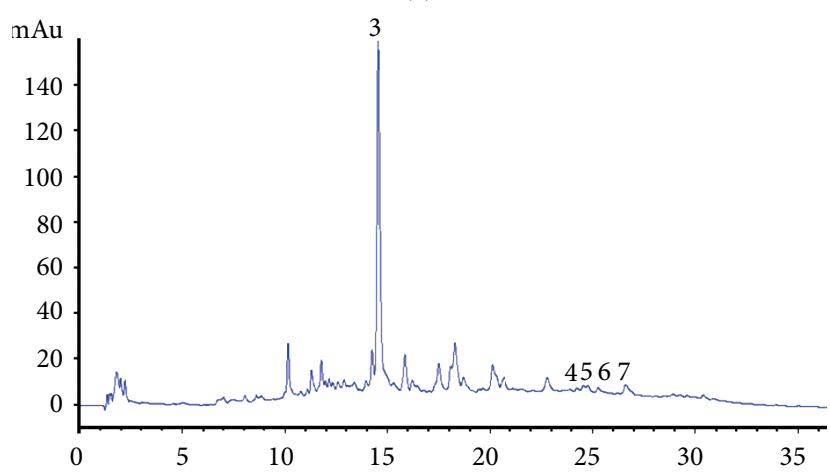

(c)

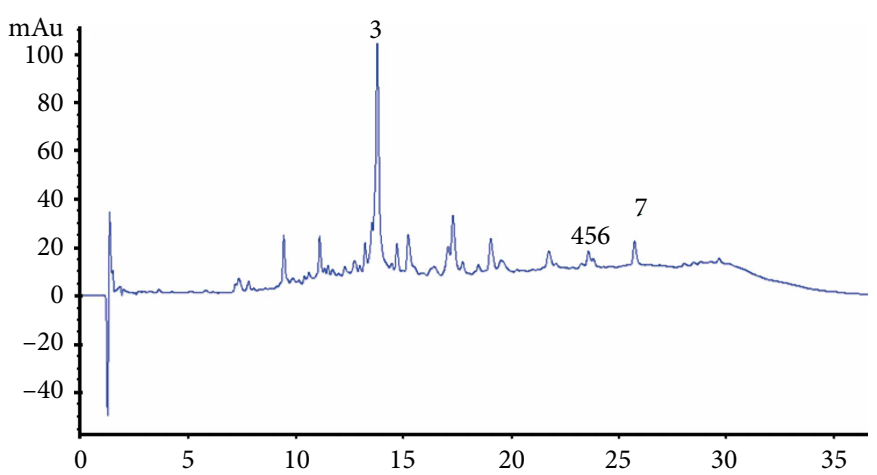

(b)

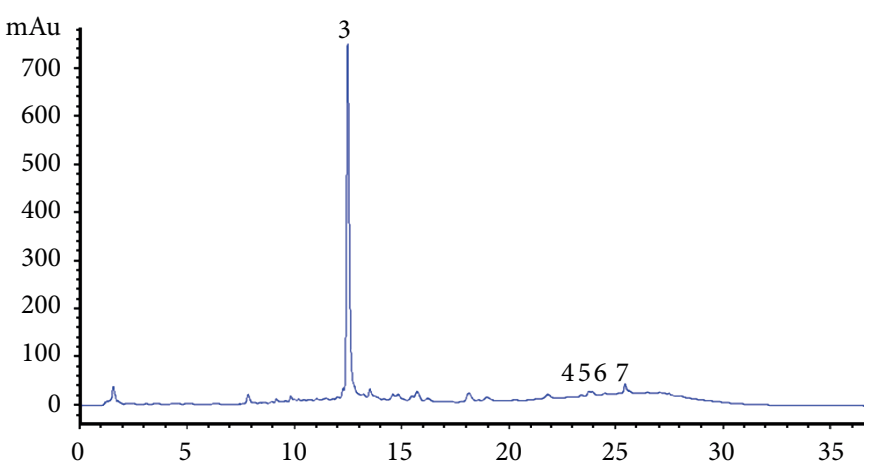

(d)

FIgURE 2: Chagalapoli (Ardisia compressa) HPLC chromatograms at $320 \mathrm{~nm}$ : (a) filtered juice; (b) partially filtered juice; (c) filtered fermented beverage; (d) partially filtered fermented beverage. 


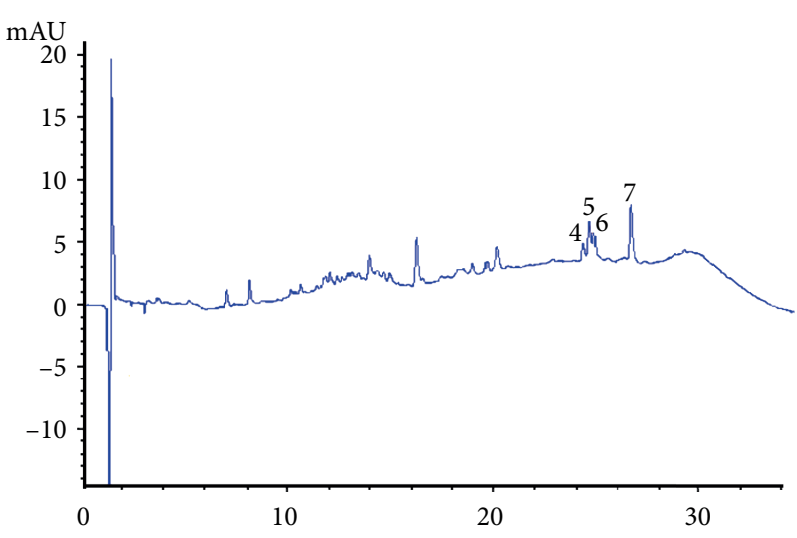

(a)

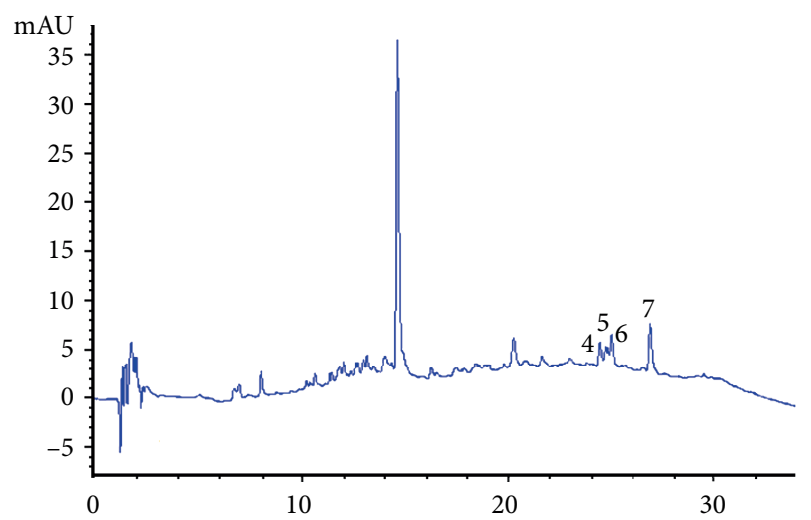

(c)

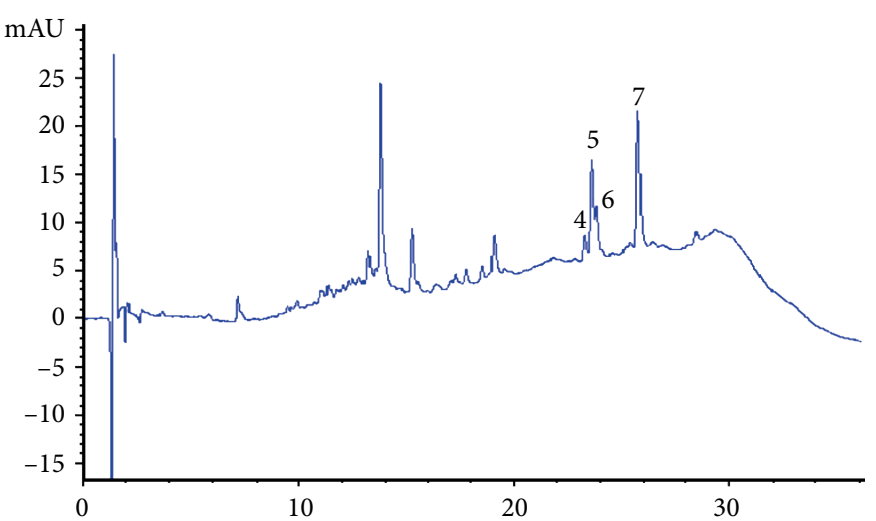

(b)

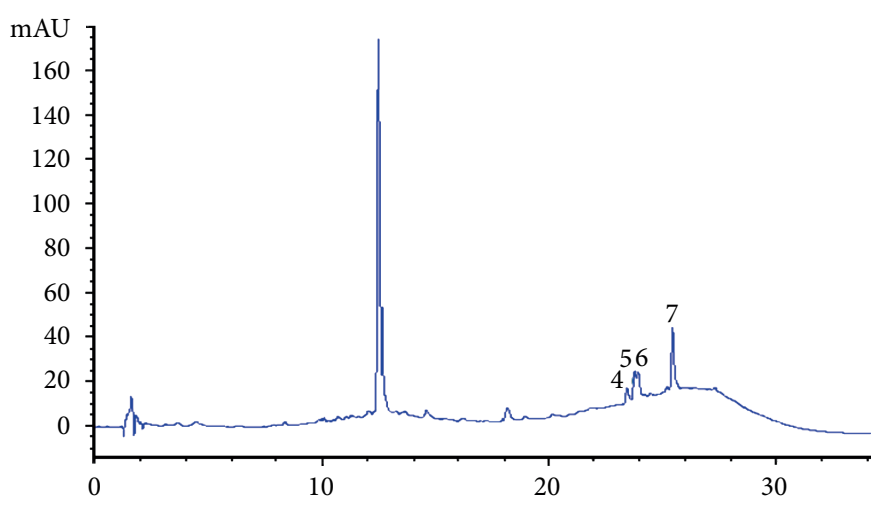

(d)

FIGURE 3: Chagalapoli (Ardisia compressa) HPLC chromatograms at $360 \mathrm{~nm}$ : (a) filtered juice; (b) partially filtered juice; (c) filtered fermented beverage; (d) partially filtered fermented beverage.

compared to the report by Kosseva et al. [20] where blueberry presented values of $155.2-164.7 \mathrm{~g} / \mathrm{kg}$, while in red grapes it was around $200 \mathrm{~g} / \mathrm{kg}$ or more at maturity. Comparing these results with reported values of blueberry, chagalapoli (Ardisia compressa) sugars are lower. There was a reduction during the fermentation, and at the end of samples $3.74 \pm 0.1 \mathrm{mg} / \mathrm{mL}$ and $3.27 \pm 0.03 \mathrm{mg} / \mathrm{mL}$ of total sugars were obtained in final products of fermented beverages. Kelebek et al. [21] reported $120.19 \mathrm{mg} / \mathrm{mL}$ in orange juice and $48 \mathrm{mg} / \mathrm{mL}$ in fermented orange juice. These results could differ since the orange is considered a citrus fruit and because the sugars present in each fruit are different. Since the methods for reducing and total sugars are different, results are not considered complementary.

The results obtained for total sugar content and reducing sugar content in the partially filtered samples showed the limitation of sugar desimentation, this may explain the variation in the results obtained.

\subsection{Analysis of Phenolic Compounds}

3.7.1. Folin-Ciocalteu Method. The total polyphenol content by the Folin-Ciocalteu method in chagalapoli (Ardisia compressa) juices was $1.8 \pm 0.03 \mathrm{mgGAE} / \mathrm{mL}$ for filtered juice and $1.75 \pm 0.1 \mathrm{mgGAE} / \mathrm{mL}$ for partially filtered juice. Similar values were previously reported by Heredia-Vásquez [3], who obtained values of $1.74 \mathrm{mgGAE} / \mathrm{mL}$ in Ardisia compressa kunth; Joaquín-Cruz, et al. [4] obtained 1.051 $\pm 43.5 \mathrm{mgGAE} / \mathrm{g}$ in chagalapoli fruit. In filtered and partially filtered fermented beverage the values decreased to $1.11 \pm 0.02 \mathrm{mgGAE} / \mathrm{g}$ and $1.59 \pm 0.19 \mathrm{mgGAE} / \mathrm{g}$, respectively. Martins de Sá et al. [7] reported $1.105 \pm 57 \mathrm{mgGAE} / \mathrm{mL}$ in a fermented jabuticaba (Myrciaria jaboticaba) beverage. Johnson et al. [22] reported a total polyphenol content of $0.3754-0.6571 \mathrm{mgGAE} / \mathrm{mL}$ in blackberry (Vaccinium spp.) fermented beverage.

3.7.2. HPLC-DAD Analysis. Total polyphenols are shown in Table 4. An increase in the total polyphenols was observed in both samples of Chagalapoli (Ardisia compressa) fermented beverages. At the beginning of the fermentation, the value was $1.07 \pm 0.04$ epichatechin $\mathrm{mg} / \mathrm{mL}$, with increases towards the end of fermentation with a final value of $1.47 \pm 0.09$ epichatechin $\mathrm{mg} / \mathrm{mL}$. The partially filtered chagalapoli sample initially presented $1.43 \pm 0.1$ epichatechin $\mathrm{mg} / \mathrm{mL}$ and at the end of fermentation had increased to $2.86 \pm 0.01$ epichatechin $\mathrm{mg} / \mathrm{mL}$. Recent studies demonstrated the same behavior in fermentations in different grape varieties. In the fermentation process, several enzymes are excreted during the metabolism of the yeast, and these enzymes could act on the conjugated phenolic compounds to release free phenolic compounds, and thus change their composition [23]. Figure 1 show the compounds identified in Ardisia compressa samples at $280 \mathrm{~nm}$ wavelength. Peaks 1 and 2 
TABle 5: Sensory analysis of chagalapoli (Ardisia compressa) fruit filtered and partially filtered fermented beverages.

\begin{tabular}{lcc}
\hline & $\begin{array}{c}\text { Filtered fermented } \\
\text { beverage }\end{array}$ & $\begin{array}{c}\text { Partially filtered fer- } \\
\text { mented beverage }\end{array}$ \\
\hline Color & $3.47 \pm 0.8^{\mathrm{b}}$ & $4.34 \pm 0.6^{\mathrm{a}}$ \\
Aroma & $3.69 \pm 0.9^{\mathrm{a}}$ & $3.72 \pm 1.2^{\mathrm{a}}$ \\
Flavour & $2.9 \pm 0.1^{\mathrm{b}}$ & $4.31 \pm 0.8^{\mathrm{a}}$ \\
\hline
\end{tabular}

Results are expressed as mean $\pm \operatorname{SE}(n=32)$. Values with same letter are not statistically different $(p<0.05)$.

correspond to catechin and epicatechin; catechin was found at $7.12 \mathrm{~min}$ up to $7.45 \mathrm{~min}$, epicatechin was found at $8.2 \mathrm{~min}$ up to $8.54 \mathrm{~min}$ in the first chromatograms, while in the chromatogram of the partially filtered fermented beverage it was observed at $11.24 \mathrm{~min}$. Figure 2 shows the juices and fermented beverage chromatograms at $320 \mathrm{~nm}$ wavelength. In partially filtered fermented beverage, a major peak is shown, which was identified as chlorogenic at $12.48 \mathrm{~min}, 14.49 \mathrm{~min}$ and $13.73 \mathrm{~min}$ for filtered beverages and at $14.52 \mathrm{~min}$ in partially filtered juice. Figure 3 shows compounds identified in Ardisia compressa beverages at $360 \mathrm{~nm}$ wavelength. Different derivatives of quercetin were identified between $24.65 \mathrm{~min}$ and $24.81 \mathrm{~min}$ for filtered beverages (juice and fermented beverages) and for partially filtered beverages they were identified at $23.23 \mathrm{~min}$ up to $23.92 \mathrm{~min}$. Kaempferol was identified at $26.6 \mathrm{~min}$ in the filtered samples and in partially filtered samples it was found at $25.72 \mathrm{~min}$ and $24.48 \mathrm{~min}$. Joaquín-Cruz et al. [4] identified 6 derivatives of quercetin with retention times of $18.61 \mathrm{~min}, 19.49 \mathrm{~min}, 19.92 \mathrm{~min}$, $20.21 \mathrm{~min}, 22.98 \mathrm{~min}$ and $23.72 \mathrm{~min}$. For the identification of kaempferol, retention times of $16.94 \mathrm{~min}$ and $17.24 \mathrm{~min}$ were obtained.

3.8. Sensory Evaluation. Fermented beverages from both batches were subjected to a sensory analysis to evaluate the degree of satisfaction of the final product, carried out with a panel of 32 untrained tasters older than 18 years. Table 5 shows the results of acceptance of each sample, it was observed that the partially filtered beverage obtained a higher acceptance value in color and flavor parameters with a difference of 0.87 and 1.41, respectively. Aroma did not present a significant difference between samples; this means that there was not a preference for any of the two fermented beverages.

\section{Conclusions}

The results of the present study demonstrated that chagalapoli fruit has the potential to be used to produce fermented beverages. It was also revealed that chagalapoli fermented beverages represent a rich source of phenolic compounds and due to their phenolic composition they may be compared to other fruit fermented beverages. This beverage can be considered as a dry spirit since the content of reducing sugars was lower than $4 \mathrm{mg} / \mathrm{mL}$. Based on the characteristics of the produced chagalapoli fermented beverages, it was concluded that there should be more extensive research with chagalapoli fruit due to its potential for development into a marketable beverage.

\section{Conflicts of Interest}

The authors declare that they have no conflicts of interest.

\section{References}

[1] H. Kobayashi, and E. De Mejía, "The genus Ardisia: a novel source of health-promoting compounds and phytopharmaceuticals," Journal of Ethnopharmacology, vol. 96, no. 3, pp. 347-354, 2005.

[2] S. P. Jácome-Hernández, "Propiedades antioxidantes y estabilidad de una bebida elaborada a partir del fruto de capulin (Ardisia compressa)," "[M.S. Thesis]," Universidad Veracruzana, Xalapa, Veracruz, 2012.

[3] J. Heredia-Vásquez, "Propiedades fisicoquímicas y antioxidantes de polvos nanoestructurados de," "Ardisia compressa," kunth. "[M.S. Thesis]," Universidad Veracruzana, Veracruz, Mexico, 2013.

[4] E. Joaquín-Cruz, M. Dueñas, L. García-Cruz, Y. SalinasMoreno, C. Santos-Buelga, and C. García-Salinas, "Anthocyanin and phenolic characterization, chemical composition and antioxidant activity of Chagalapoli (Ardisia compressa K.) fruit: A tropical source of natural pigments," Food Research International, vol. 70, pp. 151-157, 2015.

[5] R. Colorado-Vargas, "Caracterización de Chagalapoli,” ("Ardisia compressa" Subsp. Myrsinaceae), para su posible uso en la elaboracion de un alimento funcional "[M.S. Thesis]," Universidad Autónoma de Chihuahua, Chihuahua, México, 2013.

[6] S. Chandra and E. De Mejia-Gonzalez, "Polyphenolic compounds, antioxidant capacity, and quinone reductase activity of an aqueous extract of Ardisia compressa in comparison to mate (Ilex paraguariensis) and green (camellia sinensis) Teas," Journal of Agricultural and Food Chemistry, vol. 52, no. 11, pp. 3583-3589, 2004.

[7] L. Z. C. Martins de Sá, P. F. S. Castro, F. M. A. Lino et al., "Antioxidant potential and vasodilatory activity of fermented beverages of jabuticaba berry (Myrciaria jaboticaba)," Journal of Functional Foods, vol. 8, pp. 169-179, 2014.

[8] H. Li and U. Förstermann, "Red wine and cardiovascular health," Circulation Research, vol. 111, no. 8, pp. 959-961, 2012.

[9] D. R. Dias, R. F. Schwan, E. S. Freire, and R. S. Serôdio, "Elaboration of a fruit wine from cocoa (Theobroma cacao L.) pulp," International Journal of Food Science \& Technology, vol. 42, no. 3, pp. 319-329, 2007.

[10] P. Mena, A. Gironès-Vilaplana, N. Marti, and C. Garcia-Viguera, "Pomegranate varietal wines: Phytochemical composition and quality parameters," Food Chemistry, vol. 133, no. 1, pp. 108-115, 2012.

[11] M. E. S. Oliveira, L. Pantoja, W. F. Duarte, C. F. Collela, L. T. Valarelli, and R.F. Schwan, D. R. Dias, "Fruit wine produce from cagaita (Eugenia dysenterica DC) by both free and immobilised yeast cell fermentation," Food Research International, vol. 44, pp. 2391-2400, 2011.

[12] J. G. Cazorla, M. X. Vayreda, Técnicas usuales de análisis en enología, Panreac Química, S. A. Barcelona, 2000. 
[13] Office Internationale de la Vigne et du Vin (OIV), Recueil des Mèthodes Internationales D'analyse des Vins Paris, OIV, France, 1990.

[14] G. Miller, "Use of dinitrosalicylic acid reagent for determination of reducing sugar," Analytical Chemistry, vol. 31, no. 3, pp. 426-428, 1959.

[15] M. Dubois, K. A. Gilles, J. K. Hamilton, P. A. Rebers, and F. Smith, "Colorimetric method for determination of sugars and related substances," Analytical Chemistry, vol. 28, no. 3, pp. 350-356, 1956.

[16] P. S. Chow and S. M. Landhausser, "A method for routine measurements of total sugar and starch content in woody plant tissues," Tree Physiology, vol. 24, no. 10, pp. 1129-1136, 2004.

[17] V. L. Singleton and J. A. Rossi, "Colorimetry of total phenolics with phosphomolybdic-phosphotungstic acid reagents," American Journal Enology and Viticulture, vol. 16, pp. 144-158, 1965.

[18] K. Neffe-Skocinska, B. Sionek, I. Scibisz, and D. KolozynKrajewska, "Acid contents and the effect of fermentation condition of Kombucha tea beverages on physicochemical, microbiological and sensory properties," CyTA - Journal of Food, vol. 15, no. 4, pp. 601-607, 2017.

[19] P. Chowdhury and R. C. Ray, "Fermentation of jamun (Syzygium cumini L.) fruits to form red wine," ASEAN Food Journal, vol. 14, no. 1, pp. 15-23, 2007.

[20] M. Kosseva, V. K. Joshi, and P. S. Panesar, Science and Technology of Fruit Wine Production, Academic Press, London, UK, 2016.

[21] H. Kelebek, S. Selli, A. Canbas, and T. Cabaroglu, "HPLC determination of organic acids, sugars, phenolic compositions and antioxidant capacity of orange juice and orange wine made from a Turkish cv. Kozan," Microchemical Journal, vol. 91, no. 2, pp. 187-192, 2009.

[22] M. H. Johnson, A. Lucius, T. Meyer, and E. G. De Mejia, "Cultivar evaluation and effect of fermentation on antioxidant capacity and in vitro inhibition of $\alpha$-amylase and $\alpha$-glucosidase by highbush blueberry (Vaccinium corombosum)," Journal of Agricultural Food Chemistry, vol. 59, no. 16, pp. 8923-8930, 2011.

[23] Y. Zhang, S. K. C. Chang, S. J. Stringer, and Y. Zhang, "Characterization of titratable acids, phenolic compounds, and antioxidant activities of wine made from eight Mississippigrown muscadine varieties during fermentation," $L W T$ - Food Science and Technology, vol. 86, pp. 302-311, 2017. 


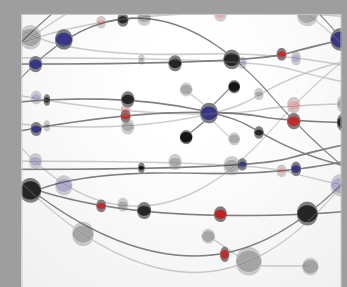

The Scientific World Journal
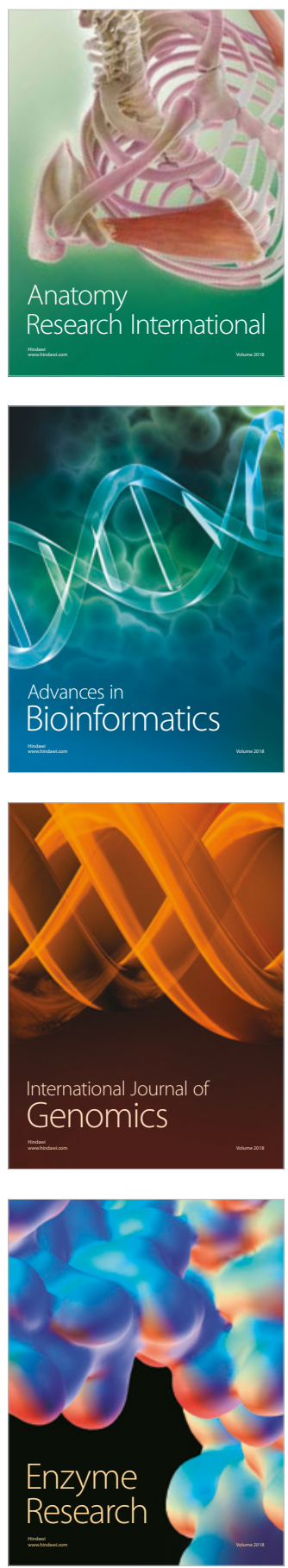
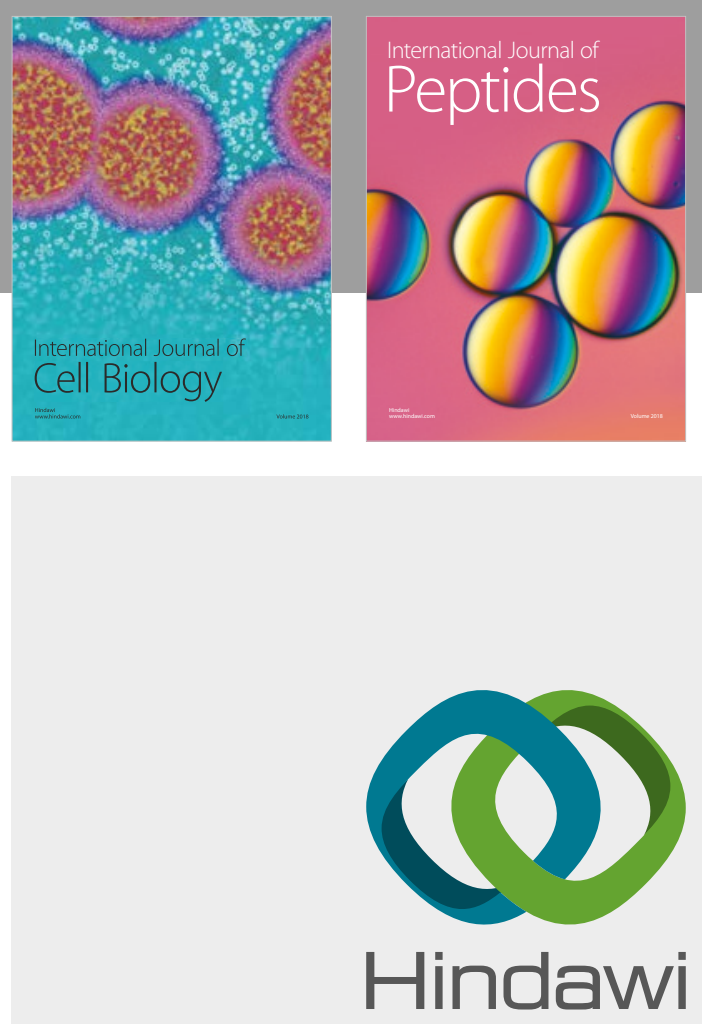

Submit your manuscripts at

www.hindawi.com
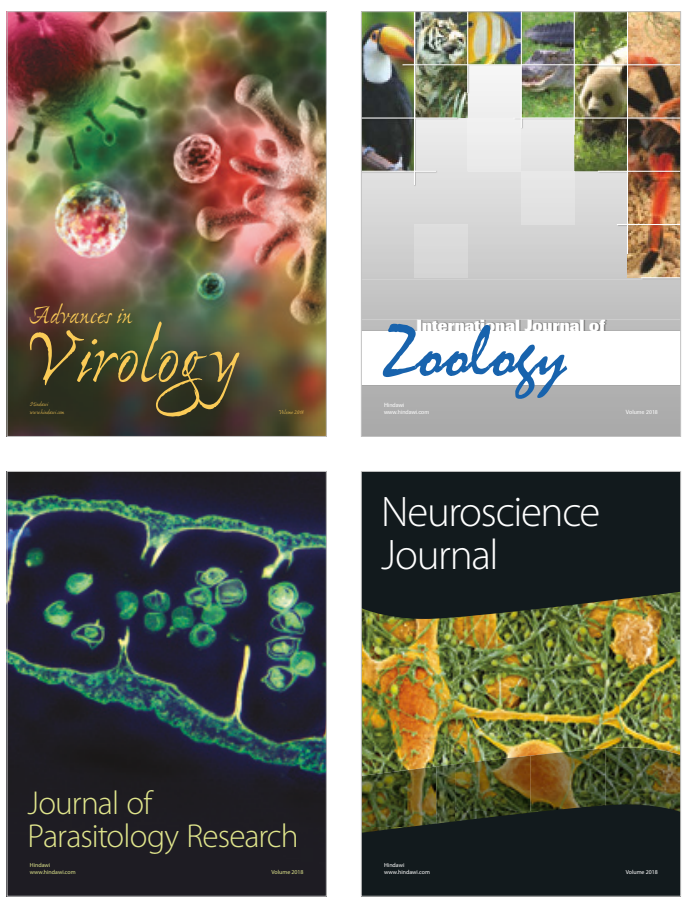
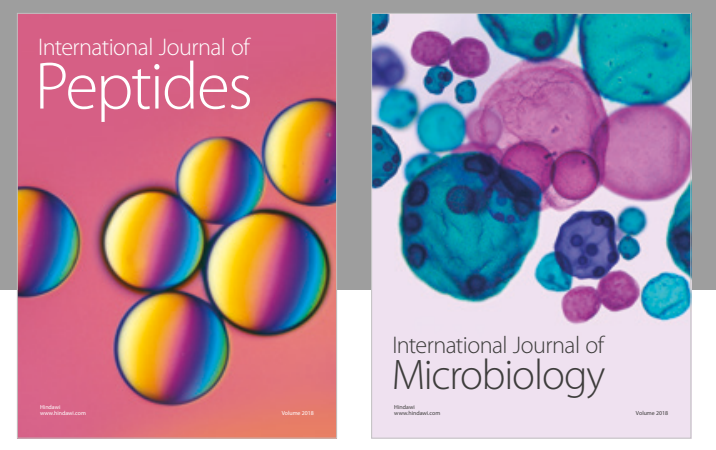

nternational Journal of Microbiology
Journal of
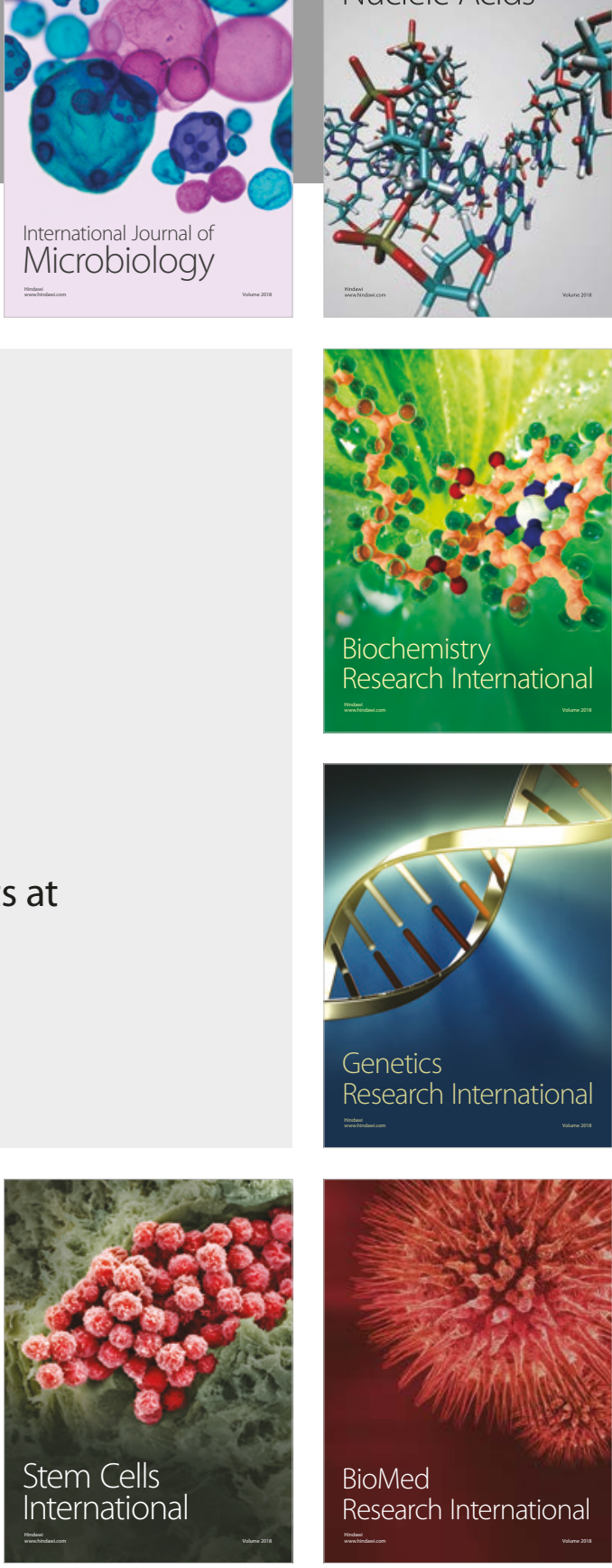
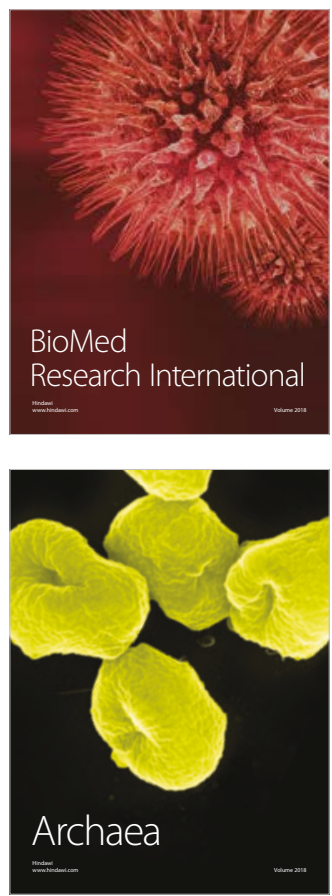